\title{
SLEEP HABITS IN NATIVE BRAZILIAN BORORO CHILDREN
}

\author{
RUBENS REIMÃO*, JOSÉ CARLOS ROSA PIRES DE SOUZA**, \\ CARLOS EDUARDO VILELA GAUDIOSO***
}

\begin{abstract}
Sleep behavior patterns in childhood are influenced by familial, cultural and environmental factors. In understanding sleep in Native Brazilian Bororo children, one should consider the influence of their culture on the child's sleep. This research analyzes sleep habits of Native Bororo children from the Meruri village, located in an Indian Reservation in the state of Mato Grosso. Fourty four children ( 24 M; 20 F) were evaluated; ages ranged from one month to 10 years, with a mean age of 4.9 years. Sleep characteristics were assessed by means of a standard questionnaire applied to the mothers. Cosleeping - sleeping together with family members - was a remarkable finding, in every child 0-2 year old and in $81.5 \%$ in the 2-10 years group. The second characteristic was sleeping with many people in the same room. There was an average of 5.1 people per room in the younger group and 3.9 people in the older group.
\end{abstract}

KEY WORDS: sleep, sleep habits, child, cosleeping, native Bororo indian, Mato Grosso.

\section{Hábitos de sono da criança indígena Bororo}

RESUMO - O padrão de sono da criança é influenciado por fatores familiares, culturais e ambientais. Para compreendermos as características do sono da criança indígena brasileira, devemos levar em consideração a influência de sua cultura. Esta pesquisa analisa hábitos de sono da criança indígena Bororo na aldeia Meruri, em reserva indígena no Mato Grosso. Quarenta e quatro crianças foram avaliadas (24 M; 20 F), com idades de um mês a 10 anos (média 4,9 anos). As características do sono foram avaliadas por meio de questionário padronizado aplicado em entrevista com as mães. O hábito de dormir junto (cosleeping) na mesma cama com familiares foi encontrado em todas as crianças abaixo de 2 anos; em $81,5 \%$, entre 2 e 10 anos. Numerosos familiares dormem no mesmo quarto. Há em média 5,1 pessoas por quarto no grupo abaixo de 2 anos e 3,9 no grupo acima de dois anos.

PALAVRAS-CHAVE: sono, hábito de dormir, infância, nativo, índio Bororo, Mato Grosso.

Sleep behavior patterns and sleep disorders in childhood are highly influenced by familial, cultural and environmental factors. In an effort to understand sleep in Native Brazilian children, one should consider the influence of their rich culture and diversity on the child's sleep ${ }^{1-7}$

Literature focusing on Native Brazilian sleep is unknown to us. Therefore, studies on sleep habits of these children are unavailable.

The objective of this research is to evaluate sleeping habits of Native Brazilian Bororo children. It is part of a broader investigation that aims to understand sleep in this ethnic group ${ }^{8-15}$.

CDS-Centro de Distúrbios do Sono, São Paulo. *Diretor do CDS-Centro de Distúrbios do Sono, MédicoAssistente da Divisão de Clínica Neurológica do Hospital das Clínicas da Faculdade de Medicina da Universidade de São Paulo; **Professor de Psicopatologia, Universidade Católica Dom Bosco (UCDB), Campo Grande, MS; ***Estudante de Graduação, Curso de Psicologia, UCDB, Campo Grande, MS. Aceite: 29outubro-1998. 


\section{METHODS}

Fourty-four Native Bororo children with ages ranging from 0 to 10 years were evaluated $(24 \mathrm{M} ; 20$ F). Mean age was 4.9 years, ranging from one month to 10 years (Table 1). Sleep characteristics were investigated through interviews with the mothers during the winter of July 1998.

The interviews were conducted from house to house, including all homes with children in this age range. Four mothers were excluded: two, because they refused to be interviewed and two because they were absent from the village. Eleven yes/no multiple choice questions and 3 short-answer questions, focusing primarily on the habit of sleeping in the same bed with family members (cosleeping) and bedroom conditions were employed to evaluate the children's sleep habits. Besides maternal interviews, in selected cases, photographic documentation of the bedrooms were taken. These will be presented elsewhere.

The Meruri village, located in an Indian Reservation, in the municipality of General Carneiro, Mato Grosso, was studied. Meruri village is $112 \mathrm{~km}$ from the nearest town, Barra do Garças.

\section{RESULTS}

The data presented are divided into two groups (Table 2): the younger group, 0-24 months and the older group, 2 to 10 years. This age division was made because sleep habits, and especially cosleeping, may be interpreted distinctly in these two age groups.

Cosleeping (bedsharing) with family members was observed in all children under 2 years of age; and in 31 out of 38 children, 2 to 10 years old $(81.5 \%)$. The 7 children that sleep alone comprise four boys (ages 4, 9, 10, 10), and three girls (ages 4, 5, 10). Among the ten year olds, 3 out of 5

Table 2. Sleep characteristics of Bororo children in the Meruri village.

\begin{tabular}{lcccc}
\hline & \multicolumn{2}{c}{$0-24$ months } & \multicolumn{2}{c}{$2-10$ years } \\
& $\mathrm{N}$ & $\%$ & $\mathrm{~N}$ & $\%$ \\
\hline Sleeps alone & & & 7 & 18.4 \\
$\begin{array}{l}\text { Sleeps with } \\
\quad \text { mother }\end{array}$ & & & & \\
$\quad$ father & 6 & 100 & 16 & 42.1 \\
$\quad$ brother & 3 & 50.0 & 10 & 26.3 \\
$\quad$ sister & 2 & 33.3 & 8 & 21.0 \\
$\quad$ grandfather & 1 & 16.6 & 9 & 23.6 \\
grandmother & & & 5 & 13.1 \\
$\quad$ others & & & & \\
In the bedroom & & & 3 & 7.8 \\
$\quad$ TV & & & & \\
$\quad$ radio & 1 & 16.6 & 6 & 15.7 \\
$\quad$ quiet & 3 & 50.0 & 24 & 63.1 \\
$\quad$ noise & 6 & 100 & 35 & 92.1 \\
Bedroom temperature & & & 3 & 7.8 \\
$\quad$ pleasant & & & & \\
$\quad$ too cold & 6 & 100 & 32 & 84.2 \\
$\quad$ too warm & & & 6 & 15.7 \\
Total & & & & \\
\hline
\end{tabular}


children sleep alone (60.0\%). Therefore, cosleeping is found in every Bororo child by the first two years of life and reduces markedly by the end of the first decade.

In our sample, cosleeping is more often found with both parents, followed by sisters, brothers, and less often grandmothers or others. In the item "others" we found 3 out of the 44 children $(6.8 \%)$ studied, which was the case of three unrelated girls sleeping together.

The mean number of beds per bedroom was 2.0 in the $0-24$ month old children; and 1.7 in the 2-10 year old children. The maximum number was 4 beds per bedroom. There was an average of 5.1 people per room in the younger group and 3.9 people in the older group. The maximum number of people was 9 .

In the younger group (0-24 months), all evaluated children slept at night on beds with mattresses. In the older group (2-10 years old), 30 out of 38 children slept at night on beds with mattresses; 2 slept on mats; 3 slept on hammocks; and 3 slept on wooden beds without mattresses called tarimba. All evaluated children covered themselves with industrially made blankets.

The homes of all evaluated children had electric light. Radios were present in the bedroom in $50 \%$ of the younger age group (0-24 months old), in $63.1 \%$ of the older age group, and in $61.3 \%$ in the entire 44 children sample.TV was present in only one bedroom of the younger children's group (16.6\%), and in $15.7 \%$ of the older group; $15.9 \%$ in the entire 44 children sample.

The bedroom was regarded as a silent atmosphere by all the mothers of children in the younger group and by $92.1 \%$ of the older group. Among the entire group of 44 children, the atmosphere was described as silent by $93.1 \%$. The noises reported were of children talking and of neighbours. Room temperature was reported as pleasant by all the mothers of children in the younger group and by $84.2 \%$ of the older group. Room temperature was reported as pleasant by $81.8 \%$ of the 44 children sample. Six children had bedrooms described as cold; none had bedrooms described as hot. However, it should be borne in mind that the interviews were conducted during cooler winter days.

Although carefully looked for, no distinction in children's care was found due to age, gendre or social status. The only exception noticed was the uniform use of beds with mattresses in the younger group, while mats, hammocks and wooden beds without mattresses were present in the older age group.

\section{DISCUSSION}

Cosleeping or bedsharing - sleeping with family members in the same bed, predominantly with both parents - was a remarkable finding in the Bororo children. All the children up to 2 years of age, and most of the children almost till the end of the first decade, show cosleeping habits. Only in the 10-year-old group we find a predominance of sleeping alone. This characteristic of Bororo children's sleep is markedly different from the data of other groups such as western urban and Asiatic populations ${ }^{16-21}$. In fact, in western urban societies cosleeping is a culturally avoided habit ${ }^{22-27}$.

A second remarkable characteristic of the Bororo children was the presence of many people and more than one bed in the same room. We noticed that the young group sleep in beds with mattresses, while the older group sleep in either hammocks, mats or wooden beds with or without mattresses. The presence of many people of the same family in the same bed or room provides greater physical proximity among family members, which means care and protection. The silence in the room and pleasant temperature create a cozy atmosphere for the child. These habits differ markedy from contemporary western urban populations, in which individual rooms and beds receive greater emphasis, even in childhood ${ }^{28-31}$.

The present research is part of a larger project in order to determine the characteristics of normal sleep and sleep disorders in the Brazilian native population, including children and adults. In our first reports, recently published, we described the sleep characteristics of the Terena children ${ }^{32,33}$. We do not know of any previous publications on the Brazilian native sleep. In the present paper we evaluated Bororo children, and found that Terena and Bororo - such distinct ethnic groups - bear the 
same typical characteristics of cosleeping. All the Terena children showed the habit of cosleeping; similar to the Bororo group in which this habit decreased only at the end of the first decade of life.

External influence from urban Brazilian culture, was partial:

A) Electric lighting and industrially made blankets were totally adopted external influences.

B) Sleeping in beds with mattresses, radios and TV were partially adopted, and in various degrees.

C) The urban individual sleeping manner, with individual rooms and beds were not assimilated at all by the Native Bororo children in the Meruri village.

Aknowledgement - We are thankful to Father Georg Lachnitt, Head of the Indian Documentation Center (IDC); Father Gonçalo Alberto Ochoa Camargo, Vice-Director and Counselor of the IDC; Mario Bordignon Essawurén, Counselor and Coordinator of the IDC; Mariza Etelvina Rosa Irola, Secretary of the IDC.To the Bororo people, for friendship and hospitality.

\section{REFERENCES}

1. Ellis EM. Watchers in the night: an anthropological look at sleep disorders. Am J Psychother 1991;45:211-220.

2. Levi-Strauss C. O pensamento selvagem. São Paulo, Companhia Editora Nacional, 1970.

3. Reimão R. Contribuição ao estudo do sono e dos distúrbios do sono na infância. Dissertação de Mestrado. Faculdade de Medicina da Universidade de São Paulo. São Paulo, 1983.

4. Reimão R. Sleep: Latin American References 1895-1992. São Paulo: SDSPMA, 1993.

5. Reimão R, Diament A. Sono na infância. São Paulo: Sarvier, 1985.

6. Reimão R, Lemmi H. Narcolepsy in childhood and adolescence. Arq Neuropsiquiatr 1991;49:260-264.

7. Rona RJ, Li L, Gulliford MC, Chinn S. Disturbed sleep: effects of sociocultural factors and illness. Arch Dis Child 1998;78:20-25.

8. Albisetti C, Venturelli AJ. Enciclopédia Bororo. Campo Grande: Museu Regional Dom Bosco, 1962.

9. Araújo FR. Bororo. São Paulo: CODAC/USP, 1987.

10. Bordignon M. Os Bororos na história do Centro Oeste Brasileiro 1716-1986. Campo Grande: Missão Salesiana de Campo Grande MS, 1986.

11. Gonçalves JRS. A luta pela identidade: o caso das relações entre índios e brancos no Brasil central. Dissertação de Mestrado. Museu Nacional, Rio de Janeiro 1982.

12. Mangolim O. Povos indígenas no Mato Grosso do Sul: viveremos por mais 500 anos. Campo Grande: CIMI, 1993.

13. Ribeiro D. Cultura e línguas indígenas no Brasil. Educação e Ciências Sociais, Volume 6. Rio de Janeiro: Centro Brasileiro de Pesquisas Educacionais, 1957.

14. Silva JR. A família etno-linguística Bororo. 3.Ed. Rio de Janeiro: Editora São José, 1973.

15. Viertler RB. Formação da sociedade Bororo. Rev Antropol 1986;29:1-39.

16. Billingham RE, Zentall S. Co-sleeping: gender differences in college students' retrospective reports of sleeping with parents during childhood. Psychol Rep 1996;79:1423-1426.

17. Cooper R, Potter A, Watson L, Yelland J. Co-sleeping in infancy. J Paediatr Child Health 1995;31:60-61.

18. Petersen SA, Wailoo MP. Interactions between infant care practices and physiological development of Asian infants. Early Hum Dev 1994;38:181-186.

19. Schachter FF, Fuchs ML, Bijur PE, Stone RK. Cosleeping problems in Hispanic American urban young children. Pediatrics 1989;84:522-530.

20. Stein MT, Colarusso CA, McKenna JT, Powers NG. Cosleeping (bedsharing) among infants and toddlers. J Dev Behav Pediatr 1997; 18:408-412.

21. Zuckerman B, Stevenson J, Bailey J. Sleep problems in early childhood: continuities, predictive factors, and behavioral correlates. Pediatrics 1987;80:664-671.

22. Byard RW. Is co-sleeping in infancy a desirable or dangerous practice? J Paediatr Child Health 1994;30:198-199.

23. Canuso R. Co-family sleeping: strange bedfellows or culturally accepted behavior. J Cult Divers 1996;3:109-111.

24. Genta MB, Reimão R, Lefèvre B. Insônia no primeiro ano de vida. Reun Neurofisiol Clin 1993;2:53-56.

25. Lozoff B, Askew GL, Wolf AW. Cosleeping and early childhood sleep problems: effects of ethnicity and socioeconomic status. J Dev Behav Pediatr 1996;17:9-15.

26. Proença C, Reimão R. Atualização em insônia do lactente. Neurobiologia (Recife) 1997;60:45-48.

27. Rath FHJ, Okum ME. Parents and children sleeping together: cosleeping prevalence and concerns. Am J Orthopsychiatry 1995;65:411-418.

28. Conder K. Sleep in child rearing: a cross cultural perspective. Midwife Health Comm Nurs 1988;24:126-127.

29. Gilford MC, Price CE, Rona RJ, Chinn S. Sleep habits and height at age 5 to 11. Arch Dis Child 1990;65:119-122.

30. McKenna JJ, Mosko SS. Sleep and arousal, synchrony and independence, among mothers and infants sleeping apart and together (same bed): an experiment in evolutionary medicine. Acta Pediatr 1994;397(Suppl 1):94-102.

31. McKenna JJ, Mosko SS, Richard CA. Bedsharing promotes breastfeeding. Pediatrics 1997;100:214-219.

32. Reimão R, Souza JCRP, Medeiros MM, Almirão RI. Sleep habits in native Brazilian Terena children in the State of Mato Grosso do Sul, Brazil. Arq Neuropsiquiatr 1998;56:703-707.

33. Reimão R, Souza JCRP, Almirão TI, Medeiros MM. Sleep characteristics in the first two years of life in native Brazilian Terena children. Rev Bras Neurol 1998;34:159-162. 